\title{
IMPLEMENTASI PROJECT BASED LEARNING UNTUK MENINGKATKAN KEMANDIRIAN DAN PRESTASI BELAJAR MAHASISWA DALAM PEMBUATAN ALAT PERAGA MATEMATIKA INOVATIF
}

\author{
Ratih Puspasari \\ STKIP PGRI Tulungagung \\ ratihpuspasari0807@yaho.com
}

\begin{abstract}
Abstrak: Penelitian ini bertujuan untuk meningkatkan kemandirian dan prestasi belajar mahasiswa dalam pembuatan alat peraga Matematika di sekolah menengah melalui pembelajaran Project Based Learning. Subyek penelitian adalah mahasiswa STKIP PGRI Tulungagung semester IV Program Studi Pendidikan Matematika tahun 2015/2016 sebanyak 40 orang dan terbagi dalam 7 kelompok. Desain penelitian yang digunakan adalah PTK dengan acuan model Kemmis dan Mc Taggart dan dilaksanakan 2 siklus. Pengambilan data dilakukan dengan pretest, lembar penilaian desain alat peraga, lembar pengamatan kerja sama, lembar penilaian psikomotorik dan lembar penilaian alat peraga. Data analisis deskriptif. Hasil dari siklus 1 disarankan ada perbaikan dalam proses pembelajaran. Pada siklus 2 dengan kelompok yang sama dilakukan analisis penilaian dengan hasil penelitian, yaitu : 1 kelompok memiliki kemampuan sangat baik dalam mendesain alat peraga, ada 4 kelompok baik dan 2 kelompok cukup baik. Pada penilaian psikomotorik telah menunjukkan 3 kelompok dengan kriteria penugasan sangat baik dan 3 kelompok baik dan 1 kelompok cukup baik. Sedangkan penilaian pada aspek kerja sama kelompok menunjukkan 1 kelompok sangat baik, 3 kelompok baik dan 3 kelompok cukup baik. Berdasarkan hasil penilaian tersebut maka Project Based Learning (PjBL) mampu meningkatkan kemandirian dan prestasi belajar mahasiswa dalam kelompok untuk membuat alat peraga dengan hasil pemikiran sendiri maupun dari alat peraga yang sudah ada.
\end{abstract}

Kata Kunci: alat peraga, project based learning (PjBL), kemandirian, prestasi belajar.

Ilmu Pengetahuan dan Teknologi yang terus berkembang hingga saat ini menuntut profesionalisme dosen dalam mengarahkan mahasiswa-mahasiswanya untuk menempatkan diri sebagai pembelajar mandiri. Artinya mahasiswa sebagai manusia dewasa diharapkan dapat memilih sendiri sumber belajar yang relevan sesuai dengan kebutuhan capaian pembelajaran.

Peranan kemandirian dalam belajar tidak bisa dipandang remeh. Hasil pengamatan peneliti dalam observasi di lapangan telah ditemukan fakta, yaitu: a) dalam mengerjakan tugas-tugas yang diberikan dosen banyak mahasiswa yang mengambil jalan pintas dengan menyalin jawaban dari teman tanpa memahami penyelesaian dari masalah tersebut. b) bila diberi tugas kelompok, sebagian mahasiswa lebih mengandalkan kemampuan teman lain untuk mengerjakan. Bagi mereka dari mana asal muasal selesaian tugas tersebut tidaklah penting. Yang terpenting adalah ada hasil pekerjaan yang dapat ditunjukkan di hadapan dosen dengan menyerahkan kertas kerjanya.

Berdasarkan hasil pengamatan di atas maka pengajaran pada tingkat pendidikan tinggi perlu mendapatkan perhatian khusus. 
Strategi pembelajaran yang digunakan dosen juga perlu dikembangkan. Tidak hanya sekedar memberikan tugas yang banyak tapi minim evaluasi, namun juga pembelajaran yang memacu kemandirian belajar dan kemampuan berpikirnya. Kemampuan belajar mandiri mutlak diperlukan mahasiswa untuk menghadapi tugas mandiri, tugas proyek maupun tugas akhir

Menurut Mujiman (2007, hal. 67) "Kemandirian Belajar dapat diartikan sebagai sifat serta kemampuan yang dimiliki siswa untuk melakukan kegiatan belajar aktif, yang didorong oleh motif untuk menguasai sesuatu kompetensi yang telah dimiliki”. Seorang siswa dikatakan mempunyai Kemandirian Belajar apabila mempunyai kemauan sendiri untuk belajar, siswa mampu memecahkan masalah dalam proses belajar matematika, siswa mempunyai tanggung jawab dalam proses belajar matematika, dan siswa mempunyai rasa percaya diri dalam setiap proses belajar matematika. Sementara itu Sumarmo (2004, hal. 4) menyatakan karakteristik yang termuat pada kemandirian belajar, adalah (1) Individu merancang belajarnya sendiri sesuai dengan keperluan atau tujuan individu yang bersangkutan, (2) Individu memilih strategi dan melaksanakan rancangan belajarnya, (3) Individu memantau kemajuan belajarnya sendiri, mengevaluasi hasil belajarnya dan dibandingkan dengan standar tertentu.

Uraian di atas dapat diambil kesimpulan bahwa ciri-ciri kemandirian belajar pada setiap siswa akan nampak jika siswa telah menunjukkan perubahan dalam belajar. Siswa belajar untuk bertanggung jawab terhadap tugas yang dibebankan padanya secara mandiri dan tidak bertanggung pada orang lain. Manfaat kemandirian dalam belajar menurut Yamin (2010, hal. 101), antara lain : (1) Memupuk tanggung jawab. (2) Meningkatkan keterampilan. (3) Memecahkan masalah. (4) Mengambil keputusan. (5) Berpikir kreatif. (6) Berpikir kritis. (7) Percaya diri yang kuat. (8) Menjadi guru bagi diri sendiri.

Pentingnya kemandirian diungkapkan oleh Yamin (2008, hal. 128) bahwa kemandirian belajar yang diterapkan oleh siswa dan mahasiswa membawa perubahan yang positif terhadap intelektualitas. Perlunya kemandirian belajar mahasiswa khususnya pada individu yang belajar matematika dan sains didukung oleh beberapa penelitian dan hasil studi. Hasil penelitian Saefullah, dkk. (2013, hal. 34) terdapat hubungan positif (searah) yang berarti antara sikap kemandirian belajar dan prestasi belajar siswa, semakin baik sikap kemandirian belajar yang dimiliki siswa, maka akan semakin baik pula prestasi belajar yang akan diraihnya, dan terdapat pula hubungan positif (searah) antara sikap kemandirian belajar yang dimiliki siswa terhadap kemampuan untuk meningkatkan prestasi belajarnya. Sikap kemandirian belajar berkontribusi sebesar 40,96\% terhadap prestasi belajar yang akan diraih siswa.

Hasil studi Hargis (2000, hal. 1) dalam temuannya menyebutkan bahwa adanya hubungan positif antara individu yang memiliki kemampuan untuk mengatur pembelajaran dan perolehan pengetahuan atau pencapaian mereka sendiri. Studi lain juga menemukan bahwa mahasiswa yang memiliki derajat self-efficacy yang tinggi menunjukkan derajat kemandirian belajar yang tinggi juga (Wongsri dkk.,2002 hal. 2).

Dari uraian di atas maka kemandirian belajar sangat diperlukan oleh pembelajar. Sebab seseorang yang tidak mempunyai kemandirian dalam belajar, tidak akan mungkin melakukan aktivitas belajar. 
Sehingga pendidikan dan pengajaran pada pendidikan tinggi perlu dikembangkan untuk memacu daya kemampuan dan kemandirian belajar mahasiswa.

Kemandirian belajar harus dimiliki setiap individu terutama yang mengikuti pendidikan tinggi (Wongsri dkk., 2002 hal. 2). Mahasiswa diarahkan menjadi pembelajar yang mandiri karena kemandirian merupakan faktor yang mempengaruhi prestasi belajar.

Prestasi belajar merupakan cerminan dari usaha belajar. Winkel (2207, hal. 109) mengatakan bahwa perbuatan belajar dalam pendidikan menghasilkan hasil belajar yang terlihat dalam prestasi belajar. Semakin baik usaha belajarnya maka semakin baik pula prestasi belajar yang di capainya. Sehingga prestasi belajar dapat dijadikan sebagai indikator keberhasilan dalam belajar.

Agar mahasiswa memiliki semangat belajar yang tinggi maka dosen selaku pengampu mata kuliah perlu menciptakan suasana belajar yang nyaman dan bersifat alami. Hal ini dilakukan agar mahasiswa belajar melalui pengalaman secara langsung dan alamiah. Artinya, belajar akan lebih bermakna jika mahasiswa "mengalami" sendiri apa yang dipelajarinya, bukan "mengetahui" menurut orang lain. Pengalaman belajar secara alamiah tersebut membawa konsekuensi terhadap pemilihan model pembelajaran yang digunakan. Model pembelajaran yang digunakan harus menekankan pada pemecahan masalah, mengarahkan mahasiswa menjadi pembelajar mandiri, mengaitkan pembelajaran pada konteks kehidupan mahasiswa sehari-hari serta menerapkan penilaian otentik.

Solusi yang ditawarkan salah satunya adalah dengan memilih model pembelajaran yang mampu menjadikan mahasiswa sebagai pengendali pembelajaran (student center) bukan pembelajaran yang didominasi dosen (teacher center). Untuk mewujudkan pembelajaran yang ideal seperti ini, maka model yang dapat diterapkan adalah dengan Project Based Learning (PjBL).

PjBL adalah pembelajaran berbasis proyek, yaitu suatu pendekatan pendidikan yang efektif berfokus pada kreativitas berpikir, pemecahan masalah, dan interaksi antara pembelajar dengan kawan sebayanya untuk menciptakan dan menggunakan pengetahuan baru (Asan, 2005 hal. 77). PjBL dipandang tepat sebagai suatu model pembelajaran yang dapat membantu mahasiswa agar memiliki kreativitas berpikir, pemecahan masalah, dan interaksi serta membantu dalam penyelidikan yang mengarah pada penyelesaian masalahmasalah nyata (Turgut, 2008 hal. 63).

$\mathrm{PjBL}$ penting untuk diterapkan pada tingkat pendidikan tinggi karena beberapa hasil penelitian pendahulu Koch, Chlosta, \& Klandt, (2006, hal. 1) menunjukkan bahwa 90\% mahasiswa yang mengikuti proses belajar dengan implementasi Project Based Learning yakin dan optimis dapat mengimplementasikan Project Based Learning dalam dunia kerja serta dapat meningkatkan prestasi akademiknya. Hasil survei Lasonen, Johanna, Vesterinen, \& Pirkko (2000, hal. 1) menunjukkan fakta bahwa $78 \%$ mahasiswa mengatakan bahwa kurikulum berbasis PjBL dapat membantu membekali mahasiswa untuk persiapan memasuki dunia kerja, karena mahasiswa belajar bukan hanya secara teori melainkan praktik di lapangan.

Bertolak dari uraian di atas maka dapat disimpulkan bahwa PjBL dapat menstimulasi motivasi, proses, dan meningkatkan prestasi belajar mahasiswa dengan menggunakan masalah-masalah yang berkaitan dengan mata kuliah tertentu pada situasi nyata. PjBL dapat diterapkan pada salah satu mata kuliah yaitu 
mata kuliah Pengembangan Media Pembelajaran Matematika. Capaian pembelajaran ini adalah mahasiswa mampu mendesain alat peraga matematika dan mewujudkan desain alat peraga tersebut menjadi alat peraga matematika tiga dimensi. Penerapan PjBL sangat realistis untuk mata kuliah pengembangan media pembelajaran matematika yang memerlukan kerja praktek. Karena kompetensi yang harus dikuasai mahasiswa setelah perkuliahan ini adalah mahasiswa mampu membuat dan menggunakan suatu alat peraga matematika yang tepat untuk pembelajaran matematika di sekolah menengah. Selain dari penguasaan kompetensi oleh mahasiswa, penerapan $\mathrm{PjBL}$ dapat dilihat dari aspek kemandirian merancang proyek, usaha kolaboratif mahasiswa dalam menyelesaikan tugas dan belajar kontekstual.

Pada penelitian ini langkah-langkah PjBL yang digunakan yaitu: (a) searching, menghadapkan mahasiswa pada masalah riil di lapangan, dan mendorong mereka mengidentifikasi masalah riil tersebut, (b) solving, mahasiswa diminta menemukan alternatif dan merumuskan strategi pemecahan masalah, (c) designing, mahasiswa dibimbing melakukan perencanaan, (d) producting/ creating, mahasiswa dibimbing memproduksi alat peraga matematika yang telah di desain pada tahap sebelumnya, (e) evaluating, mahasiswa dibimbing melakukan pengujian produk, (f) sharing, mahasiswa diminta presentasi antar kelompok (Sunarto, 2005 hal. 6)

Berdasarkan uraian di atas, PjBL dapat dijadikan alternatif dalam perkuliahan pengembangan media pembelajaran matematika. Adapun tujuan penelitian ini adalah untuk meningkatkan kemandirian dan prestasi belajar mahasiswa dalam pembuatan alat peraga Matematika sekolah menengah melalui pembelajaran Project Based Learning.

\section{Metode Penelitian}

Penelitian ini menggunakan desain Penelitian Tindakan Kelas (PTK). Langkah penelitian mengacu pada model Kemmis dan McTaggart yaitu: perencanaan, tindakan, pengamatan dan refleksi. Subyek penelitian ini adalah Mahasiswa Program Studi Pendidikan Matematika STKIP PGRI TULUNGAGUNG yang sedang menempuh mata kuliah Pengembangan Media Pembelajaran Matematika pada Semester 4 Tahun Ajaran 2015/2016. Subyek penelitian sejumlah 40 mahasiswa yang terbagi dalam 7 kelompok. Adapun obyek penelitian meliputi kemandirian merancang proyek, usaha kolaboratif mahasiswa, penguasaan psikomotorik dan kemampuan menilai produk dalam rangka pembelajaran kontekstual.

Penelitian ini terdiri dari 2 siklus, dengan jangka waktu penelitian adalah 1 semester yaitu selama 14 kali pertemuan. Teknik pengambilan data dilakukan dengan pretest mahasiswa, lembar penilaian desain alat peraga matematika, lembar pengamatan kerja sama dalam pembuatan alat peraga, lembar penilaian psikomotorik dan lembar penilaian alat peraga.

Data dianalisis dengan analisis deskriptif. Hasil uji awal kemampuan dirangkum, sedangkan dari instrumen lain diperoleh skor untuk tiap kelompok. Kemudian dianalisis persentase untuk menentukan kriteria hasil penilaian, yaitu sangat baik, baik, cukup baik, kurang baik dan sangat tidak baik untuk desain alat peraga. Kriteria sangat baik, baik, cukup baik, kurang baik, dan sangat tidak baik untuk penilaian 
psikomotorik dan penilaian produk alat peraga.

\section{Hasil Penelitian dan Pembahasan}

\section{Hasil}

\section{Penelitian Siklus 1}

\section{a. Tahap Perencanaan}

Pertemuan pertama diawali dengan penyampaian rencana pembelajaran yang akan dilaksanakan dalam 1 semester. Selanjutnya Dosen membagikan soal pretest untuk mengetahui kemampuan awal mahasiswa tentang alat peraga matematika. Hasil pretest telah menunjukkan pengetahuan mahasiswa tentang alat peraga matematika ternyata masih kurang. Hal ini dibuktikan dengan masih banyak beberapa pertanyaan yang belum terjawab dengan tepat. Hasil observasi dosen melalui wawancara dengan mahasiswa juga menunjukkan $34 \%$ mahasiswa pernah diajar guru matematika di SMA/SMK dengan alat peraga yang variatif dan $66 \%$ mahasiswa lainnya jarang diajar dengan menggunakan alat peraga. Selanjutnya dosen membagi kelas menjadi 7 kelompok dan memberikan tugas kepada masing-masing mahasiswa untuk melakukan pengamatan dan wawancara terhadap guru mata pelajaran matematika SMP/ SMA.

Tabel 1. Daftar Nama Kelompok Dan Nama Alat Peraga Matematika

\begin{tabular}{ccl}
\hline Siklus & Kelompok & \multicolumn{1}{c}{ Nama Alat Peraga } \\
\hline \multirow{4}{*}{1} & 1 & Bintang Ajaib Segi Lima \\
& 2 & Puzzle Sudut \\
& 3 & Perkalian Matriks \\
& 4 & Tabel Kebenaran Logika \\
& 5 & Domino Fungsi Trigonometri \\
& 6 & Blok Aljabar \\
& 7 & Jaring-Jaring Kubus \& Balok \\
\hline \multirow{3}{*}{2} & 1 & Puzzle Logaritma \\
& 2 & Papan Ajaib Jumlah Sudut Sin \\
& 3 & \& Cos \\
& &
\end{tabular}

\begin{tabular}{ll}
4 & Papan Pemangkatan \\
5 & Logaritma \\
6 & Galaksi Transformasi \\
7 & Dakon FPB \& KPK \\
\hline
\end{tabular}

Pada pertemuan kedua, mahasiswa melakukan analisis terhadap permasalahan yang terkait dengan alat peraga matematika yang dihadapi guru-guru matematika di lapangan. Hasil observasi masing-masing mahasiswa selanjutnya didiskusikan dalam satu kelompok untuk membuat rancangan alat peraga yang akan dibuat. Rancangan alat peraga berisi: 1) judul alat peraga, 2) tujuan pembuatan alat peraga, 3) alat dan bahan yang diperlukan, 4) cara pembuatan, 5) cara kerja alat, 6) skema rangkaian alat peraga dan 7) kalkulasi biaya. Hasil diskusi menunjukkan ada 3 kelompok yang desain rancangan alat peraganya belum matang, yaitu kelompok 4,6, dan 7. Hasil penilaian terhadap kemandirian kelompok dalam merancang alat peraga matematika terangkum dalam Tabel 2

Tabel 2 Hasil Penilaian Kemandirian Merancang Alat Peraga Matematika

\begin{tabular}{cclcl}
\hline $\begin{array}{c}\text { Ke- } \\
\text { Lom } \\
\text { pk }\end{array}$ & $\begin{array}{c}\text { Kemandi } \\
\text { rian (\%) }\end{array}$ & Kriteria & $\begin{array}{c}\text { Kemand } \\
\text { irian } \\
(\%)\end{array}$ & Kriteria \\
\hline 1 & $58,43 \%$ & $\begin{array}{l}\text { Cukup } \\
\text { Baik }\end{array}$ & $90,28 \%$ & $\begin{array}{l}\text { Sangat } \\
\text { Baik } \\
\text { Cukup }\end{array}$ \\
\hline 2 & $55,31 \%$ & $\begin{array}{l}\text { Cukup } \\
\text { Baik }\end{array}$ & $68,37 \%$ & Baik \\
3 & $76,75 \%$ & Baik & $84,12 \%$ & Baik \\
4 & $60 \%$ & Kurang & $77,18 \%$ & Baik \\
5 & $77,18 \%$ & $\begin{array}{l}\text { Baik } \\
\text { Baik }\end{array}$ & $84.68 \%$ & Baik \\
6 & $54,87 \%$ & $\begin{array}{l}\text { Kurang } \\
\text { Baik }\end{array}$ & $80,87 \%$ & Baik \\
& & $\begin{array}{l}\text { Sangat } \\
\text { Tidak }\end{array}$ & $66,25 \%$ & Cukup \\
7 & $48,18 \%$ & $\begin{array}{l}\text { Baik } \\
\text { Baik }\end{array}$ & & \\
\hline
\end{tabular}

\section{b. Tahap Tindakan}

Setiap kelompok mulai bekerja membuat alat peraga sesuai dengan desain rancangan alat peraga yang sudah disiapkan pada pertemuan 
sebelumnya. Pembuatan proyek alat peraga ini dikerjakan masing-masing kelompok secara bersama-sama di laboratorium matematika. Selama proses pengerjaan proyek alat peraga, dosen keliling sambil mengamati kerja sama kelompok yang mengarah pada kolaborasi kelompok. Hasil penilaian kerja sama kelompok pada tabel 3 menunjukkan ada 3 kelompok yang masih belum kompak dalam membangun kerja sama kelompok, yaitu kelompok 4,5 dan 7. Hal ini dikarenakan ada beberapa mahasiswa yang mendominasi pendapat, beberapa mahasiswa malas dan enggan untuk menyelesaikan proyek, desain alat peraga tidak sesuai dengan yang diharapkan sehingga ada mahasiswa yang kecewa dengan temannya dan berhenti melanjutkan proyek. Hasil pengamatan tersebut ditunjukkan pada Tabel 3.

\begin{tabular}{|c|c|c|c|c|}
\hline \multirow{2}{*}{$\begin{array}{c}\text { Ke- } \\
\text { Lom } \\
\text { pok }\end{array}$} & \multicolumn{3}{|c|}{ Siklus 1} & Siklus 2 \\
\hline & $\begin{array}{l}\text { Kemandi } \\
\operatorname{rian}(\%)\end{array}$ & Kriteria & $\begin{array}{c}\text { Keman } \\
\text { dirian } \\
(\%)\end{array}$ & $\begin{array}{c}\text { Kriteri } \\
\mathbf{a}\end{array}$ \\
\hline 1 & $43 \%$ & $\begin{array}{l}\text { Sangat } \\
\text { Tidak Baik }\end{array}$ & $67,37 \%$ & $\begin{array}{l}\text { Cukup } \\
\text { Baik }\end{array}$ \\
\hline 2 & $62,63 \%$ & $\begin{array}{l}\text { Cukup } \\
\text { Baik }\end{array}$ & $76,61 \%$ & Baik \\
\hline 3 & $68,33 \%$ & $\begin{array}{l}\text { Cukup } \\
\text { Baik }\end{array}$ & $83,33 \%$ & Baik \\
\hline 4 & $56,39 \%$ & $\begin{array}{l}\text { Kurang } \\
\text { Baik }\end{array}$ & $79 \%$ & Baik \\
\hline 5 & $54,26 \%$ & $\begin{array}{l}\text { Kurang } \\
\text { Baik }\end{array}$ & $73,81 \%$ & $\begin{array}{l}\text { Cukup } \\
\text { Baik }\end{array}$ \\
\hline 6 & $69 \%$ & $\begin{array}{l}\text { Cukup } \\
\text { Baik }\end{array}$ & $90,81 \%$ & $\begin{array}{l}\text { Sangat } \\
\text { Baik }\end{array}$ \\
\hline 7 & $53,33 \%$ & $\begin{array}{l}\text { Kurang } \\
\text { Baik }\end{array}$ & $\begin{array}{c}71,34 \\
\% \\
\end{array}$ & $\begin{array}{l}\text { Cukup } \\
\text { Baik }\end{array}$ \\
\hline
\end{tabular}

Setelah desain alat peraga dibuat menjadi produk nyata berwujud tiga dimensi, selanjutnya mahasiswa melakukan uji coba penggunaan alat peraga dan mempresentasikannya di kelas. Saat presentasi masing-masing anggota kelompok harus terlibat aktif, yaitu bertugas sebagai: (a) penyaji materi, (b) memperagakan alat, (c) menjawab pertanyaan dan (d) menyusun notulen hasil diskusi. Penilaian psikomotorik dilakukan pada saat mempresentasikan alat peraga di depan kelas karena ketika presentasi yang terlihat adalah kemampuan individu terhadap penguasaan proyek yang sudah dikerjakan. Hasil penilaian terdapat pada Tabel 4.

\section{Tabel 4 Hasil Penilaian Psikomotor}

\begin{tabular}{|c|c|c|c|c|}
\hline \multirow[b]{2}{*}{$\begin{array}{c}\text { Ke- } \\
\text { Lom } \\
\text { pok }\end{array}$} & \multicolumn{2}{|r|}{ Siklus 1} & \multicolumn{2}{|c|}{ Siklus 2} \\
\hline & $\begin{array}{l}\text { Kemandi } \\
\text { rian }(\%)\end{array}$ & Kriteria & $\begin{array}{c}\text { Keman } \\
\text { dirian } \\
(\%)\end{array}$ & $\begin{array}{l}\text { Kriteri } \\
\quad \mathbf{a}\end{array}$ \\
\hline 1 & $44,38 \%$ & $\begin{array}{l}\text { Kurang } \\
\text { Baik }\end{array}$ & $73,75 \%$ & Baik \\
\hline 2 & $46 \%$ & $\begin{array}{l}\text { Kurang } \\
\text { Baik }\end{array}$ & $70,62 \%$ & $\begin{array}{l}\text { Sangat } \\
\text { Baik }\end{array}$ \\
\hline 3 & $63,82 \%$ & Baik & $78,55 \%$ & $\begin{array}{l}\text { Sangat } \\
\text { Baik }\end{array}$ \\
\hline 4 & $60,05 \%$ & Baik & $66,38 \%$ & Baik \\
\hline 5 & $54,72 \%$ & $\begin{array}{l}\text { Cukup } \\
\text { Baik }\end{array}$ & $70 \%$ & $\begin{array}{l}\text { Sangat } \\
\text { Baik }\end{array}$ \\
\hline 6 & $76,11 \%$ & $\begin{array}{l}\text { Sangat } \\
\text { Baik }\end{array}$ & $62,22 \%$ & Baik \\
\hline 7 & $55,11 \%$ & $\begin{array}{l}\text { Cukup } \\
\text { Baik }\end{array}$ & $60,46 \%$ & Baik \\
\hline
\end{tabular}

\section{c. Pengamatan}

Pengamatan oleh peneliti dilakukan selama Proses tindakan, efek tindakan dan hasil tindakan. Hal ini terintegrasi dengan setiap tahapan seperti telah diuraikan di atas.

\section{d. Refleksi}

Refleksi ini dilakukan untuk menilai pelaksanaan tindakan selama proses kegiatan pembelajaran berlangsung. Refleksi dilaksanakan secara kolaboratif, yaitu diskusi di kelas antara dosen dengan mahasiswa. Hal ini dimaksudkan untuk mengungkap 
permasalahan yang muncul serta strategi pemecahan masalah untuk perbaikan tindakan pada siklus berikutnya. Diskusi dengan mahasiswa dilaksanakan pada pertemuan ke 9, yaitu sesaat setelah semua kelompok sudah mempresentasikan alat peraga yang dibuat. Refleksi juga dilakukan oleh dosen lain yang berperan sebagai observer. Sehingga hasil refleksi pada siklus 1 benar-benar objektif

Berikut ini kesimpulan yang diperoleh dari refleksi siklus 1:

(a) Pengetahuan mahasiswa tentang alat peraga matematika masih kurang, (b) Hanya $34 \%$ mahasiswa yang pernah diajar guru matematika di SMA dengan alat peraga yang variatif, (c) Keterbatasan kemampuan mahasiswa dalam mencari literatur, (d) Kerja sama dalam kelompok masih belum kompak sehingga menghambat diskusi. (e) Ada mahasiswa yang masih malu-malu untuk bertanya, (f) Hanya $67 \%$ mahasiswa yang memahami tujuan diberikannya mata kuliah pengembangan media pembelajaran matematika, (g) Kemampuan mahasiswa dalam merancang /mendesain alat peraga belum sesuai harapan.

\section{Penelitian Siklus 2}

\section{a. Tahap Pra Perencanaan}

Siklus 2 dilaksanakan mulai pertemuan ke 10. Berdasarkan refleksi siklus 1, maka dilakukan perbaikan pada siklus 2 yaitu : (1) dosen memberikan pengetahuan tentang alat peraga matematika termasuk contohcontohnya, (2) Membekali mahasiswa mengenai trik - trik mencari ide dan literatur untuk inspirasi pembuatan alat peraga. (3) memberi kesempatan mahasiswa untuk bersama-sama mencari literatur di perpustakaan dan internet dengan panduan dari dosen. Kegiatan-kegiatan di atas dimaksudkan untuk meminimalisasi kurangnya pengetahuan mahasiswa yang mempengaruhi kemampuannya membuat desain alat peraga dengan baik. Kegiatan bersama sama mencari literatur juga dapat meningkatkan kekompakan dalam kelompok.

\section{b. Tahap Perencanaan}

Seperti pada siklus 1, pelaksanaan siklus 2 pada tahap perencanaan adalah pengidentifikasian dan analisis mahasiswa tentang keberadaan alat peraga matematika. Hal ini dilaksanakan pada pertemuan ke 11 . Setelah menganalisis dan mengkaji literatur dari perpustakaan maupun internet, selanjutnya masing-masing kelompok berdiskusi untuk membuat rancangan alat peraga matematika. Pada pertemuan ini, seluruh kelompok telah mengumpulkan rancangan alat peraganya. Namun demikian masih ada sebagian kelompok yang draf rancangan alat peraganya belum lengkap dan belum selesai. Penilaian kemandirian dalam membuat rancangan alat peraga terdapat pada tabel 3 .

\section{c. Tahap tindakan}

Tahapan tindakan diawali dengan pembuatan desain alat peraga matematika oleh setiap kelompok selanjutnya mewujudkannya dalam bentuk 3 dimensi. Pengamatan kerja sama dilakukan dan hasil analisis terdapat pada tabel 3. Setelah itu, setiap kelompok mempresentasikan alat peraga buatannya. Seluruh anggota harus terlibat aktif dengan peran yang berbeda dari presentasi sebelumnya.

\section{d. Refleksi}

Refleksi dilakukan pada akhir pembelajaran siklus 2. Refleksi dilakukan dengan pengamatan dan diskusi dengan mahasiswa. Hasil refleksi merekomendasikan berkaitan dengan masalah pemahaman tentang konsep matematika. Ternyata pemahaman 
konsep tentang matematika belum sepenuhnya dikuasai mahasiswa. Dalam satu topik bahasan materi, sebagian anggota kelompok masih ada yang belum paham dengan konsep matematika yang berkaitan dengan alat peraganya sehingga hal ini mempengaruhi kinerja proyek. Pemahaman tentang materi matematika yang kurang dikuasai oleh mahasiswa sangat besar pengaruhnya dalam merancang, membuat dan mempresentasikan alat peraga tersebut.

Kekompakan antar anggota kelompok juga berpengaruh dalam menyelesaikan proyek alat peraga. Sampai siklus 2 berakhir ternyata kekompakan kelompok masih kurang. Kemampuan individu yang sudah dibagi secara heterogen dalam 7 kelompok juga masih kurang seimbang. Hal ini disebabkan karena meskipun secara akademis seimbang, namun faktor kekritisan berpikir, kreativitas dan kemampuan menerjemahkan ide tidak dapat disamakan

\section{Pembahasan}

Pembelajaran Project Based Learning menekankan pada tiga pilar, yaitu kontekstual, kolaboratif dan otonomi pembelajar. Otonomi pembelajar mengisyaratkan pada konsep belajar mandiri yang dalam penelitian ini ditekankan pada kemandirian mendesain proyek, yaitu merancang suatu alat peraga matematika yang akan dibuat. Selanjutnya, kolaboratif ditekankan pada kerja sama yang sinergis antar anggota kelompok dalam mencapai tujuan, yaitu membuat alat peraga sesuai rancangan yang telah disepakati oleh satu kelompok. Pada penelitian ini, pembelajaran kontekstual dilakukan mahasiswa dengan belajar tentang alat peraga melalui melihat, mengamati, mencoba serta memberikan penilaian terhadap alat peraga yang telah dipelajarinya.

\section{Kemandirian Kelompok Merancang Alat Peraga Matematika}

Hasil analisis tentang kemandirian kelompok dalam merancang alat peraga matematika pada siklus 1 dan siklus 2 menunjukkan perbedaan. Pada siklus 1, terdapat 2 kelompok yang berkemampuan baik dalam merancang alat peraga matematika, yaitu kelompok 3 dengan nama "Perkalian Matriks" dan kelompok 5 dengan alat "Domino Fungsi Trigonometri". Ada 2 kelompok dengan kriteria cukup baik, yaitu: kelompok 1 dengan alat "Bintang Ajaib Segi lima" dan kelompok 2 dengan nama "Puzzle Sudut". Sedangkan kelompok yang masuk pada kriteria kurang baik adalah kelompok 4 "Tabel Kebenaran Logika" dan kelompok 6 "Blok Aljabar“. 1 kelompok yang termasuk kriteria sangat tidak baik, yaitu kelompok 7 dengan nama alat "Jaring-Jaring Kubus dan Balok".

Pada umumnya kekurangan dari hasil merancang alat peraga ini adalah terletak pada penuangan ide yang dikaitkan dengan konsep materi, modifikasi alat peraga yang sudah ada, bahan yang digunakan, dan cara penggunaan alat.

Pada siklus 2 terjadi peningkatan jumlah kelompok yang berkriteria baik dalam merancang alat peraga matematika. Kelompok 1 yang semula dalam kriteria cukup baik, pada siklus 2 meningkat menjadi sangat baik dengan alat peraga "Puzzle Logaritma".

Kemudian kelompok 3,4,5 dan 6 berkriteria baik. Sedangkan kelompok 2 tetap dalam kriteria cukup baik dengan alat peraga "Papan Ajaib Jumlah Sudut Sin dan Cos". Kemampuan kelompok 7 mengalami peningkatan dari sangat tidak baik menjadi cukup baik dengan alat peraga "Pembuktian Volum Limas". 


\section{Kolaborasi Kelompok dalam Membuat Alat Peraga Matematika}

Hal kedua yang diteliti adalah pengamatan terhadap usaha kolaboratif dalam kelompok. Kolaborasi dalam kelompok ditunjukkan adanya kerja sama yang sinergis antar anggota kelompok. Setiap anggota memiliki peran yang tidak dapat dipisahkan, meskipun ada pembagian tugas tetapi tanggung jawab tidak terbatas pada tugasnya. Bersama -sama saling melengkapi dan mengingatkan untuk mencapai tujuan kelompok yang dalam hal ini adalah membuat alat peraga matematika semaksimal mungkin.

Pada siklus 1 dan 2 terdapat perbedaan terkait dengan kriteria kerja sama dalam tiap kelompok. Pada siklus 1, kerja sama kelompok belum menunjukkan kriteria baik. Namun demikian ada 3 kelompok yang menunjukkan kerja sama kolaboratifnya dengan kriteria cukup baik. 3 kelompok dengan kriteria kurang baik dan 1 kelompok dengan kriteria sangat tidak baik.

Setelah dilakukan perbaikan maka pada siklus 2 semua telah terjadi peningkatan, yang mana ada 1 kelompok yang semula kerja samanya cukup baik meningkat tajam menjadi sangat baik, yaitu kelompok 6. Tiga kelompok menjadi berkriteria baik dan 3 kelompok lain dengan kriteria cukup baik.

Kemampuan berkolaborasi pada siklus 1 relatif rendah karena dipengaruhi banyak faktor, yaitu: (1) masing-masing anggota masih memerlukan penyesuaian diri dengan anggota kelompok lain untuk menjadi sebuah tim yang solid, (2) kesulitan dalam menyatukan ide pemikiran yang berbeda-beda menjadi satu desain alat peraga utuh, (3) kekompakan kelompok masih dalam tahap pembentukan. (4) ada mahasiswa yang mendominasi suatu kelompok sehingga menganggap ide pemikiran lebih bagus dari pada ide pemikiran anggota yang lain. (5) ada yang merasa kecewa karena desain konsep alat peraganya merasa diabaikan dan dianggap tidak layak. Pada siklus 2 sudah menunjukkan peningkatan pesat dari siklus 1. Setelah bertemu 8 kali pertemuan, antar anggota kelompok lebih saling mengenal karakter dan kemampuan masing-masing sehingga memudahkan koordinasi antar kelompok sehingga kekompakannya terjaga yang berujung pada kolaborasi yang solid.

\section{Penilaian Psikomotorik}

Penilaian kemampuan psikomotorik dilakukan terhadap kelompok yang sedang mempresentasikan proyek alat peraga yang telah dibuat. Hasil penilaian psikomotorik pada siklus 1 menunjukkan hanya ada 1 kelompok yang berkriteria sangat baik, yaitu kelompok 6 dengan alat peraga "blok aljabar". Ada 2 kelompok dengan kriteria baik, yaitu : kelompok 3 "Perkalian Matriks" dan kelompok 4 "Tabel Kebenaran Logika". 2 kelompok berkriteria cukup baik yaitu: kelompok 5 "Domino Fungsi Trigonometri" dan kelompok 7 "Jaring Jaring Kubus dan Balok". Serta 2 kelompok lain yang dengan kriteria kurang baik kemampuan psikomotoriknya, yaitu kelompok 1 "Bintang Ajaib Segi Lima" dan kelompok 2 "Puzzle Sudut"

Pada siklus 2, secara umum kemampuan psikomotoriknya meningkat. Ada 3 kelompok menjadi berkriteria sangat baik dan 3 kelompok dengan kriteria baik. Hanya ada 1 kelompok yang justru mengalami penurunan, yaitu kelompok 6 yang semula sangat baik menjadi berkriteria baik. Hal ini dapat disebabkan oleh penguasaan materi yang berbeda terhadap kedua jenis alat peraga yang dihasilkan serta kemampuan yang berbeda dari 
setiap anggota kelompok yang berperan dalam presentasi alat peraga matematika.

\section{Penilaian Alat Peraga Matematika}

Pada pembelajaran kontekstual, mahasiswa diberi tugas untuk memberikan penilaian terhadap alat peraga yang telah dibuat oleh kelompok lain. Hasil penilaian alat peraga oleh mahasiswa pada siklus 1 menunjukkan ada 2 alat peraga yang dinilai cukup baik, yaitu alat peraga "Tabel Kebenaran Logika" dan "Blok Aljabar". Sementara menurut penilaian dosen, kedua alat peraga tersebut berkriteria sangat tidak baik dan cukup baik.

Penilaian mahasiswa memberikan hasil kriteria cukup baik ada 3 kelompok dan 2 kelompok dengan kriteria alat peraga kurang baik. Penilaian yang dilakukan dosen memberikan kriteria yang lebih rendah dibandingkan penilaian mahasiswa, kecuali untuk alat peraga "Puzzle Sudut" yang dinilai cukup baik, tetapi penilaian mahasiswa menyatakan bahwa alat peraga tersebut kurang baik.

Penilaian alat peraga pada siklus 2 memberikan hasil yang lebih baik daripada siklus 1 baik penilaian oleh mahasiswa maupun oleh dosen. Penilaian mahasiswa menunjukkan ada 4 kelompok yang alat peraganya meningkat menjadi berkriteria baik, 2 kelompok berkriteria cukup baik serta 1 kelompok turun kriteria menjadi kurang baik, yaitu kelompok 2 dengan alat peraga "Papan Ajaib Jumlah Sudut Sin dan Cos". Penilaian terhadap kelompok 2 ini sama dengan hasil penilaian oleh dosen. Kekurangan yang nampak nyata adalah pemahaman konsep yang kurang baik sehingga cara menerjemahkan ide kurang tepat.

Penilaian dosen terhadap kelompok lain menunjukkan hanya ada 2 alat peraga yang termasuk dalam kriteria baik, yaitu alat peraga "Kataku Matriks" oleh kelompok 3 dan alat peraga "Dakon FPB \& KPK" oleh kelompok 6. Hal ini ternyata berkaitan dengan kemampuan kolaboratif kelompok. Kelompok 6 memiliki kemampuan kerja sama yang sangat baik sedangkan kelompok 3 dengan kemampuan baik. Kerja sama yang baik akan menghasilkan produk yang baik sesuai dengan tujuan yang diharapkan. Sementara itu, 3 kelompok dalam kategori cukup baik dan masih ada 2 kelompok dengan alat peraga yang kurang baik.

Penilaian oleh mahasiswa dan dosen menunjukkan perbedaan meskipun dengan pedoman penilaian yang sama. Hal ini dikarenakan banyak faktor yang mempengaruhi, antara lain perbedaan pemahaman konsep matematika. perbedaan wawasan tentang alat peraga matematika, perbedaan pengalaman serta tidak bisa dipungkiri ada faktor subjektivitas mahasiswa ketika menilai hasil karya teman sendiri. Namun demikian melihat perbedaan hasil penilaian yang tidak terlalu mencolok, dapat dikatakan bahwa kemampuan mahasiswa dalam mengevaluasi sudah cukup baik.

Adapun penilaian peningkatan dari masing-masing kriteria ditinjau dari aspek kemandirian dan prestasi belajar pada masingmasing siklus digambarkan pada Gambar 1, Gambar 2, dan Gambar 3 berikut ini. 


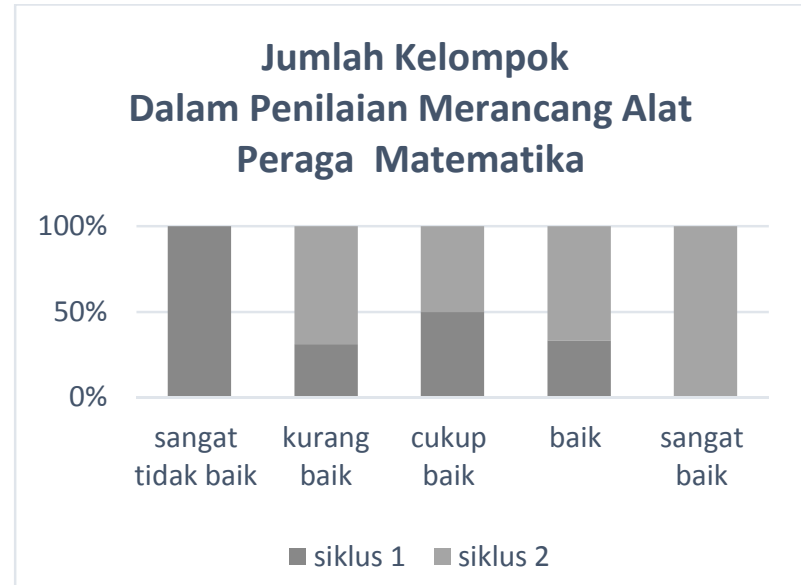

Gambar 1 Jumlah Kelompok Hasil Penilaian Kemandirian Merancang Alat Peraga Matematika

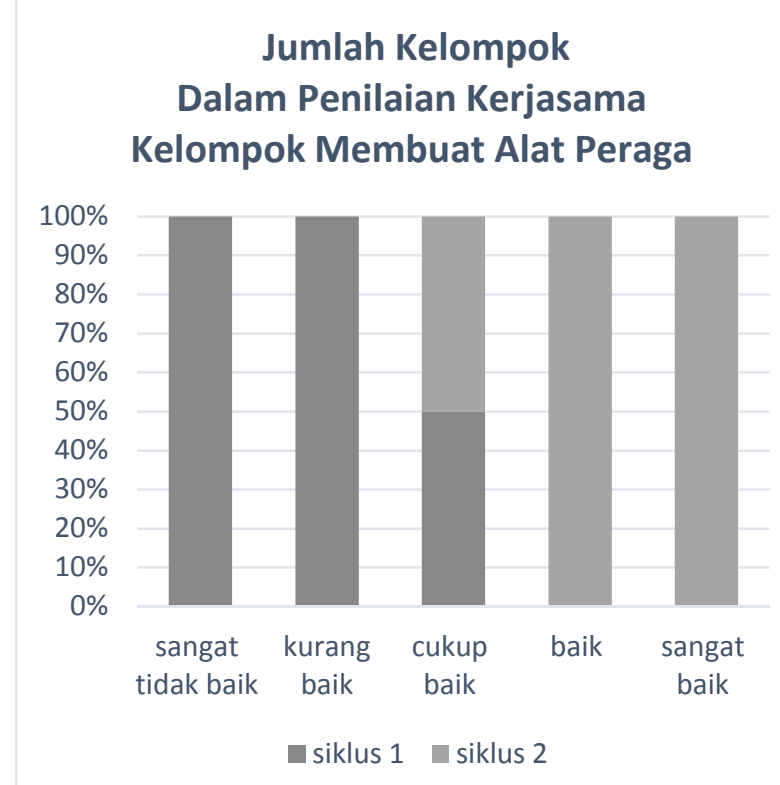

Gambar 2 Jumlah Kelompok Hasil Penilaian Kerja sama Membuat Alat Peraga Matematika

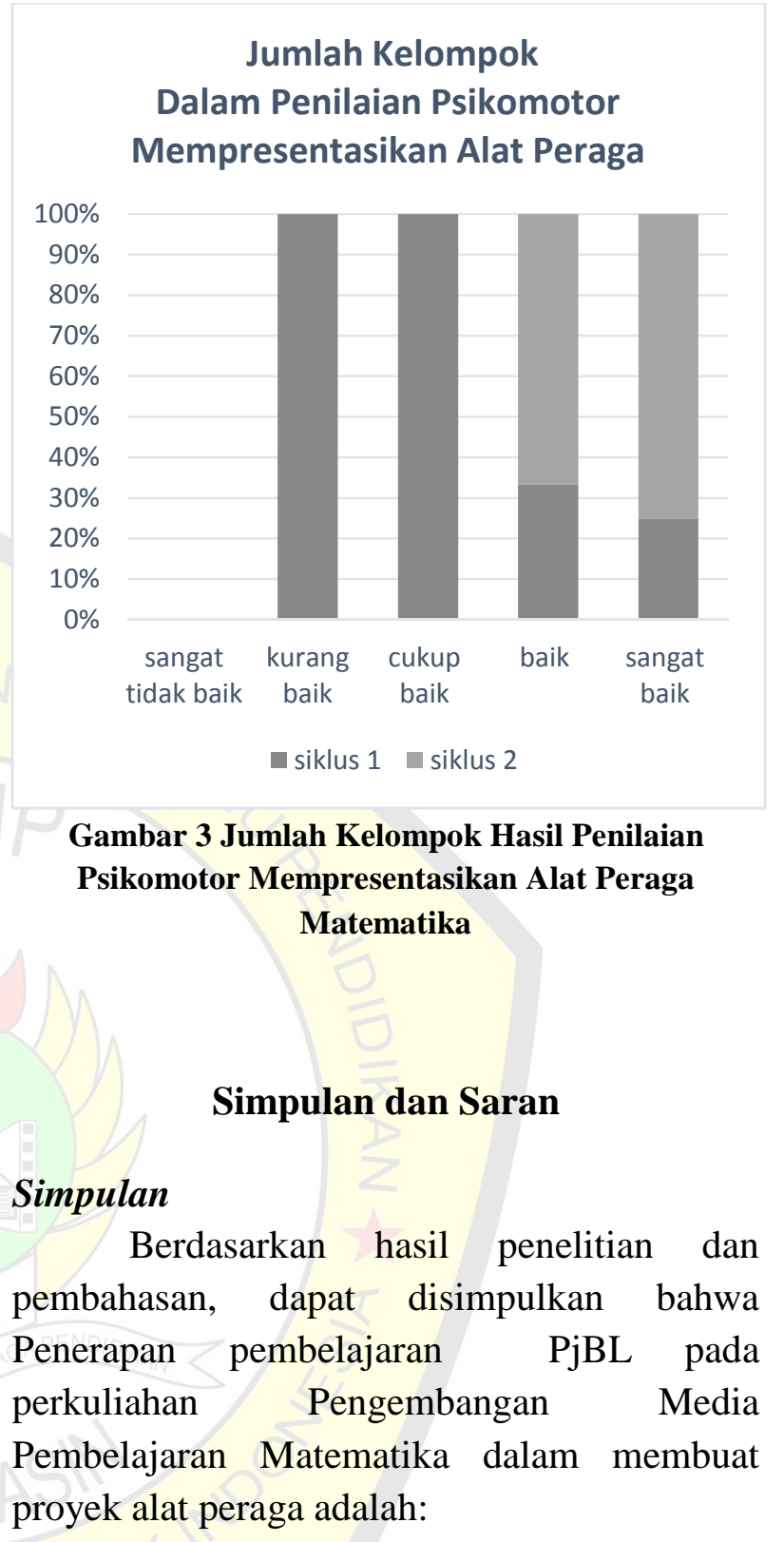

1. Cukup efektif dilihat dari aspek kemandirian kelompok merancang alat peraga matematika, yaitu adanya peningkatan kelompok dengan kriteria kemandirian yang lebih baik pada siklus 2 (5 kelompok) dibandingkan pada siklus 1 (2 kelompok).

2. Cukup efektif dilihat dari aspek kerja sama kelompok dalam membuat alat peraga matematika, yaitu adanya peningkatan kelompok dengan kriteria kerja sama yang lebih baik pada siklus 2 
(4 kelompok) dibandingkan pada siklus 1 yang mana belum ada kelompok yang memiliki kemampuan kerja sama yang baik.

3. Dapat digunakan untuk melihat peningkatan penguasaan psikomotorik mahasiswa. Pada siklus 1 , hanya ada 3 kelompok dengan penguasaan psikomotorik baik dan meningkat pada siklus 2 yang mana seluruh kelompok menjadi berkriteria baik.

\section{Saran}

Saran yang dapat diberikan adalah:

1. Pembelajaran Project Based Learning pada perkuliahan pengembangan media pembelajaran matematika Program Studi Pendidikan Matematika seharusnya menerapkan keaktifan pembelajaran yang merangsang keaktifan mahasiswa

2. Mata kuliah Pengembangan Media Pembelajaran Matematika Program Studi Pendidikan Matematika akan lebih baik jika diberikan pada mahasiswa semester 6 yang sudah memiliki bekal perkuliahan rencana pembelajaran sekaligus sebagai persiapan magang di sekolah.

\section{Daftar Pustaka}

A Saefullah, P. Siahaan, I M Sari. (2013). Hubungan antara sikap kemandirian belajar dan prestasi belajar siswa kelas $\mathrm{X}$ pada pembelajaran fisika berbasis portofolio. Jurnal Wahana Pendidikan Fisika 1 (2013) 26-36. ISSN: 2338-1027.

Asan, A dan Haliloglu, Z. (2005). Implementing Project Based Learning In Computer Classroom. The Turkish Online Journal of Educational Technology - TOJET, volume 4 Issue 3. Diakses 15 April 2017 dari

http://www.tojet.net/articles/v4i3/4310.p df.

Hargis, J (2000) The Self-Regulated Learner Advantage: Learning Science on the Internet. Diakses tanggal 14 April 2017 dari

https://translate.google.com/translate?hl =id\&sl=en\&u=http://ejse.southwestern.e du/article/view/7637/5404\&prev=search.

Koch, Chlosta. S, \& Klandt. H. (2006). Project Seminar Business Plan Development-An Analysis Of Integrative Project-Based Project-Based Entrepreneurship Education. Journal of Asia Entrepreneurship and Sustainability. Volume II (2). May. Page 1-16. Diakses tanggal 14 April 2017 dari www.asiaentrepreneurshipjournal.com/A JESII2Johann.pdf.

Lasonen, Johanna, Vesterinen, \& Pirkko. (2000). Finland Work-Based Learning in Vocational Higher Education Programmes: A Finish Case of Project Learning. Paper Presentation. Institut for Educational Research University of Jyvakyla. Page 3-18. Diakses tanggal 14 April 2017 dari https://eric.ed.gov/?id=ED448275.

Mujiman, H. (2007). Manajemen Pelatihan Berbasis Belajar Mandiri. Yogyakarta: Mitra Cendekia.

Sumarmo, U. (2004). Pengembangan Berpikir Matematik Tingkat Tinggi pada Siswa SLTP dan SMU serta Mahasiswa Strata Satu (S1) melalui berbagai Pendekatan 
Pembelajaran. Bandung, Laporan Penelitian Pascasarjana UPI. Bandung : Tidak Dipublikasikan.

Sunaryo,Soenarto. (2005). Pembelajaran berbasis proyek dan pembelajaran berbasis masalah. Makalah, Pelatihan Model Pembelajaran KBK yang diselenggarakan oleh P3AI UNY.

Turgut, Halil. (2008). Prospective Science Teachers' Conceptualizations About Project Based Learning. International Journal of Instruction. Volume I. No. 1. 61-79.

Winkel, W.S. (2007). Psikologi Pengajaran. Yogyakarta : Media Abadi.

Wongsri,N., Cantwell, R.H., Archer, J. (2002). The Validation of Measures of SelfEfficacy, Motivation and self-Regulated Learning among Thai tertiary Students. Paper presented at the Annual Conference of the Australian Association for Research in Education, Brisbane, December 2002.

Yamin, Martinis, H. (2010). Desain Pembelajaran Berbasis Tingkat Satuan Pendidikan. Jakarta: Gaung Persada Press Jakarta. 